\title{
TCF7L1 wt Allele
}

National Cancer Institute

\section{Source}

National Cancer Institute. TCF7L1 wt Allele. NCI Thesaurus. Code C150340.

Human TCF7L1 wild-type allele is located in the vicinity of 2p11.2 and is approximately

$177 \mathrm{~kb}$ in length. This allele, which encodes transcription factor 7-like 1 protein, is involved in Wnt pathway-dependent transcriptional regulation. 